\title{
OBITUARY: Dr John Alfred Lloyd
}

The death of John Lloyd in May 1999 at the tragically early age of 51 is a severe blow to his many friends and admirers in the Society. Since the early 1970s John had played a series of major roles in the work of the Society: directing fieldwork and post-excavation projects, serving with great dedication on Council (almost without a break from the mid1970s until his death) and on the Publications Committee, as editor of Libyan Studies (in 1989), as Honorary Secretary (1984-87, 1989-92) and as Head of Mission from 1996-1998. He was a hugely respected figure in Libyan archaeology and played a vital role in fostering and encouraging the careers of many Libyan national and international scholars who shared his fascination for the country and its heritage.

Whilst he was studying English as an undergraduate at Manchester, he started working as a student volunteer on the excavations of Professor Barri Jones. After graduation he initially embarked on a publishing career with Cambridge University Press, but he continued excavating in his spare time, including spending a few months at the new rescue

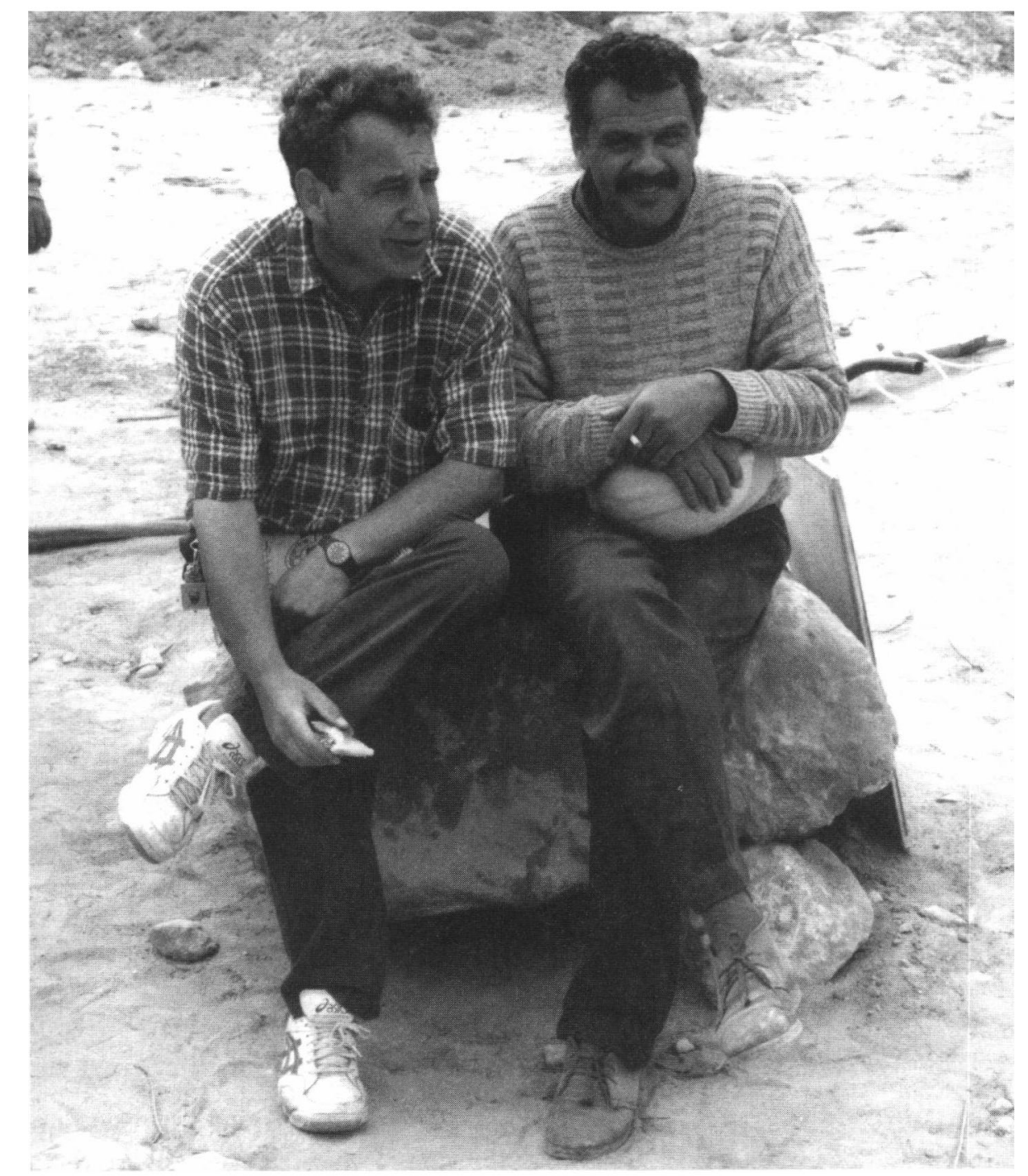

John Lloyd (pictured left) with Abdussalem Kawash at Euesperides in 1996. 
excavations that had started at Benghazi in Libya in 1971. This 'chance encounter' was to change the course of his life. Clearance for development of a Turkish Ottoman cemetery there in the suburb of Sidi Khrebish was destroying extensive remains of the Greek and Roman city of Berenice. At the invitation of the Libyan Department of Antiquities, the Society for Libyan Studies had mounted an emergency operation to try to salvage the archaeology. In November 1972, at the age of 24, John Lloyd was asked by the Society to take over the excavations as its Field Director. He spent the greater part of the next three years in Benghazi, completing a major excavation at Sidi Khrebish, coordinating a small army of workmen and specialists almost all his own age or older. The excavation generated enormous quantities of data, the study of which he also coordinated with immense commitment and patience, editing a series of five major volumes (Excavations at Sidi Khrebish, vol. I, 1977, vol. II, 1980, vol. III.1 and III.2, 1985, vol. IV.1, 1998) published by the Society for Libyan Studies over the next twenty years on every aspect of life in the ancient city over almost a thousand years, from the third century BC to the coming of Islam, an 'archaeological history' of a Mediterranean city that has probably only been rivalled by the work of the several international teams of excavators at Carthage in Tunisia. He was co-editor, with Graeme Barker and Joyce Reynolds, of the volume of conference papers, Cyrenaica in Antiquity (1985) and, with David Mattingly, of the special edition of Libyan Studies 20, issued in book form as Libya: Research in Archaeology, Environment, History and Society 1969-1989 (1989).

He joined the Department of Ancient History at Sheffield in 1977 as a lecturer in classical archaeology, before moving to Oxford's Institute of Archaeology in 1988, where he remained until his final illness. His impact as a teacher and research supervisor may be judged by the large number of his former students still active in the field.

His research interests gradually expanded in other areas of the ancient world, with important field survey and excavation projects (and publications) in Italy, Greece, Turkey and Britain. It was during fieldwork in Italy in September 1998 that he was first taken ill with what transpired to be a brain tumour. He was a particularly influential figure in the development of new techniques of field survey archaeology, and co-edited with Graeme Barker Roman Landscapes: Archaeological Survey in the Mediterranean Region (1991), a book arising from an international conference at the British School at Rome. The achievements of his fieldwork in Italy and Greece underpinned his concluding study, where he wrote of the entirely unsuspected 'busy countryside' of villages, villas, farms and cottages that was being revealed by survey archaeologists like him in every Mediterranean country. He was a strong advocate of such work in Libya too and was a close advisor for the UNESCO Libyan Valleys Survey.

Libya always remained at the core of his academic work and in recent years he had resumed work in Cyrenaica, directing rescue excavations for the Society with a colleague from Benghazi's Garyunis University at Euesperides, the first Greek colony at Benghazi. Their excavations (see most recently Libyan Studies 29, 1998, 145-68) demonstrated that the city was founded earlier than supposed, in the sixth century $\mathrm{BC}$, surviving till it was replaced by Berenice in the third century $\mathrm{BC}$, as well as illuminating how the new colony was supported by its agricultural hinterland, its trading contacts with the eastern Mediterranean, and the processes of social interaction between incoming Greeks and indigenous Libyans.

John Lloyd was an exceptionally modest man who constantly downplayed his achievements, but his archaeology was characterized by meticulous and careful scholarship made to last, whether in his own research or as a gifted and painstaking editor for the publications of the Society for Libyan Studies and the British School at Rome. That he achieved such remarkable and enduring results in his Libyan, Greek and Italian fieldwork 


\section{OBITUARIES}

was in part because of the modesty, sensitivity and integrity he brought to his professional relations. He had a tremendously strong sense of the importance of doing the right thing by his collaborators, his colleagues in the UK and abroad, his authors, his field teams, the students he taught at Sheffield and Oxford, and the family of which he was so proud. Burly and saturnine, he alternated between studied gloom and sparkling fun, between caution about his own archaeological achievements and generosity in his judgement of and support for other scholars. He set standards of professionalism few archaeologists emulate; his fieldwork has given us new understanding of ordinary life in towns and villages and farms throughout the ancient world; and in his caring for the profession of archaeology, and how it should be done to the highest standards, he had a profound influence on the careers of scores of archaeologists in Britain and abroad fortunate enough to be touched by his wisdom and wit.

The Society extends its deepest sympathy to John's children and to his wife, Vicki, herself a Sidi Khrebish veteran and long-serving editorial assistant for the Society's publications.

\section{Graeme Barker and David Mattingly}

\section{OBITUARY: Professor Geraint Dyfed Barri Jones}

The sudden death on 16th July of Barri Jones at the age of 63 represents another tragic loss to the Society for Libyan Studies and more generally to Libyan archaeology. His involvement with Libyan archaeology dates back to the late 1960s, when he assisted Charles Daniels in Fezzan and then undertook his own excavations at Tocra and Euesperides. Subsequently, he co-directed the UNESCO Libyan Valleys Project from 1979-1989 and played an important role in bringing the archive of materials from John Ward-Perkins' work on the Severan forum and basilica complex to press. He served on Council on several occasions (1972-76, 1978-83, 1988-1992), Executive Committee (1980-83), on the Richard Goodchild memorial committee (1970-76) and was Chairman from 1983 to 1988.

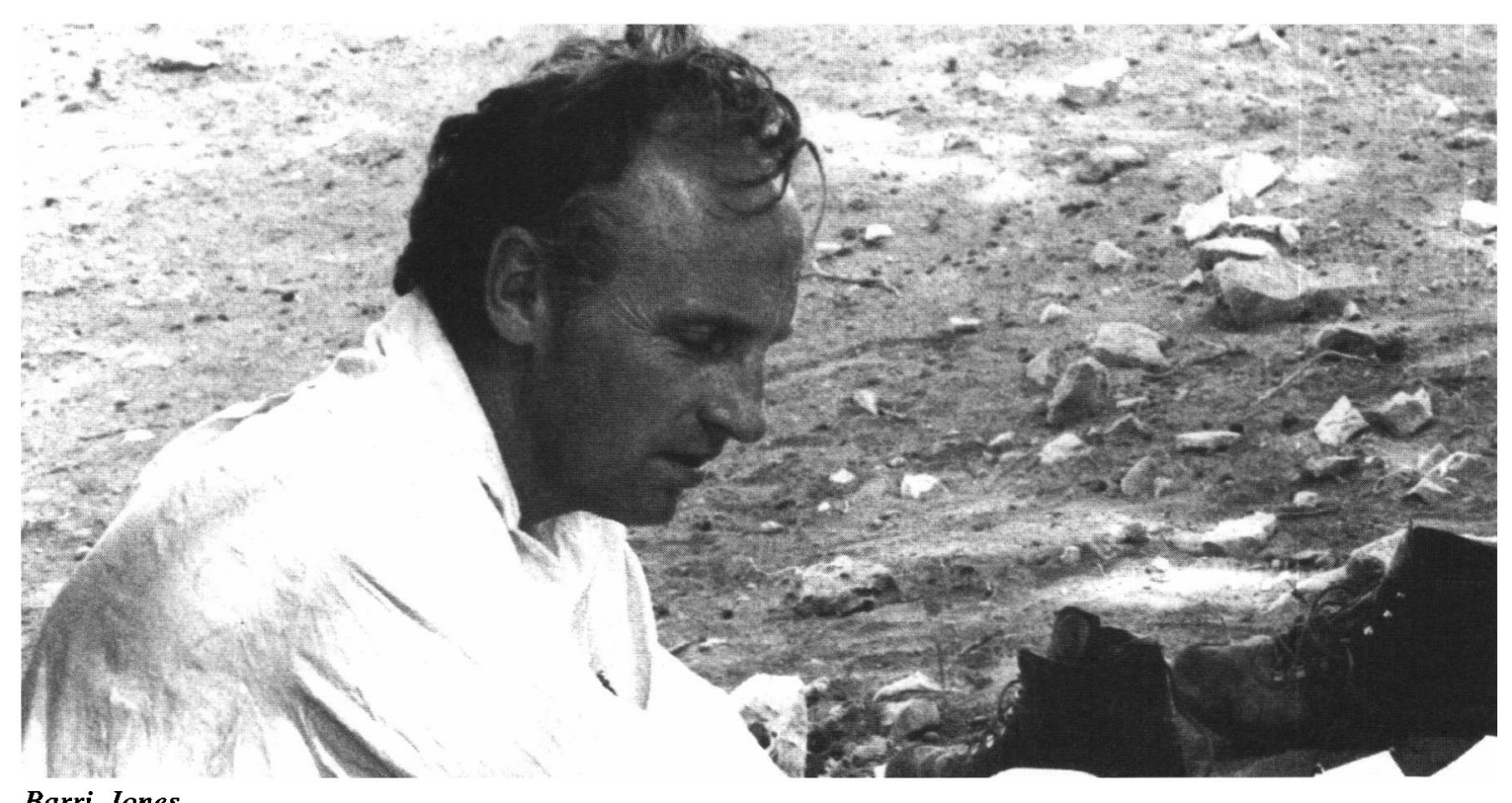

